\section{RESPIRATION AND THE ASSIMILATION OF CARBON DIOXIDE}

A $\mathrm{N}$ account of work by C. H. Werkman, L. O. Krampitz and R. G. Wood of Iowa State College on the assimilation of earbon dioxide during respiration was given on October 13 during the Autumn Meeting of the U.S. National Academy of Sciences.

The concept of heterotrophic assimilation of carbon dioxide was first established in 1935 by Wood and Werkman, while investigating the dissimilation of glycerol with the propionic acid bacteria. They observed the molar correlation between carbon dioxide disappearance and suceinic acid formation and proposed the reaction: pyruvate $+\mathrm{CO}_{2} \rightarrow$ oxaloacetate, to account for this fixation of carbon dioxide. The latter four-carbon dicarboxylic acid serves as the oxidizing agent for the glycerol, resulting in the formation of suecinic acid.

The concept of carbon dioxide assimilation has recently been applied to many other heterotrophic forms, including the liver tissue of mammals. It is in this tissue that the role of carbon dioxide fixation has been shown to be of fundamental importance with regard to respiration. Oxaloacetate is the cardinal compound in the main respiratory mechanism of the tissue. Consequently elucidation of the mechanism of its formation is of fundamental importance. Direct evidence for the fixation reaction has been obtained with a bacterial enzyme preparation from M. lysodeikticus, which is capable of bring. ing about the decarboxylation of oxaloacetate, that is, the reverse of fixation reaction. Thus far attempts to carboxylate pyruvate have failed. This may be due to an unfavourable equilibrium, that is, the breakdown of oxaloacetate is greatly favoured. On the other hand, pyruvate as such may not be the compound with which carbon dioxide unites but rather a derivation of pyruvate. With ${ }^{13} \mathrm{C}$ as a tracer it was possible, however, to demonstrate the fixation reaction using oxaloacetate. Decarboxylation of oxaloacetate was carried out in the presence of the enzyme and $\mathrm{NaHCO}_{3}$ with an enriched ${ }^{13} \mathrm{C}$ content. The reaction was allowed to continue until the original oxaloacetate concentration was halved. The residual carbon dioxide was removed and the remaining oxaloacetate was decarboxylated to pyruvate and earbon dioxide and the latter thus obtained determined for ${ }^{13} \mathrm{C}$. The concentration of ${ }^{13} \mathrm{C}$ was substantially above normal.

The eriticism that a chemical exchange of carbon dioxide with carboxyl group, analogous to the exchange of deuterium with ionizable hydrogen, may take place was investigated. Oxaloacetate spontaneously decarboxylates "slowly. An experiment similar to the above one was performed omitting the enzyme, and the residual oxaloacetate decarboxylated. The ${ }^{13} \mathrm{C}$ content of this carbon dioxide was normal.

The possibility of the enzymatic exchange of carbon dioxide with carboxyl groups of other keto acids was investigated, with an enzyme capable of oxidizing pyruvate to acetate and carbon dioxide. An experiment was conducted in which the oxidation was permitted until one half of the pyruvate remained. The residual pyruvate was decarboxylated and the ${ }^{13} \mathrm{C}$ content of the carbon dioxide was found normal. Similarly, the oxidation of $\alpha$-keto glutarate to suc- cinate was carried out, and likewise the normal ${ }^{13} \mathrm{C}$ content of carbon dioxide obtained.

Thus it has been demonstrated that the exchange reaction is specific for oxaloacetate, and apparently does not oceur in other keto acids. The exchange reaction in oxaloacetate is essentially 3 - and 1-carbon addition or a fixation reaction.

\section{GAME PRESERVATION IN BURMA}

THE annual report on game preservation in

Burma for the year ending March 31, 1940 (Rangoon, Supt. Govt. Printing, Burma, 1941) shows that this matter is treated in Burma with the serious spirit it demands. The present policy aims at providing a sufficient number of sanctuaries to ensure that no species of Burman bird or animal becomes extinet. The following list of sanctuaries will indicate how this laudable effort is carried out under the able game warden, a member of the Burma Forest Service. It is a pity that India as a whole and the British Colonies have not made similar attempts at game preservation. There are seven sanctuaries situated in North and South Burma: Pidaung (Myitkyina), 278 sq. miles; Shwe-u-daung (E. Katha), 81 sq. miles, with another $45 \mathrm{sq}$. miles situated in the neighbouring Federated Shan States; Maymyo (summer headquarters of Government of Burma), 49 sq. miles; Moscos Islands (Tavoy), 19 sq. miles; Kahilu (Thatôn), 62 sq. miles; Mulayit (Thaungyin), 53 sq.

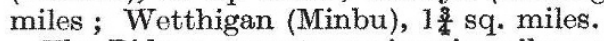

The Pidaung sanctuary is primarily constituted to protect elephants, bison, saing, sambhur, hog deer, pig, tiger, leopard, bear, pea-fowl, pheasant, jungle fowl, partridge and quail. Of these it is reported that elephant, bison and saing continue to increase, though elephants only spend part of their time in the sanctuary. On the other hand, there is a marked reduction in sambhur and hog deer found in the open plains; this is attributed to tigers and wild dogs. Four tigers are to be shot by the keepers of the sanctuary and as many wild dogs as possible, as also crows which are a serious pest to bird life in the sanctuary. Those acquainted with big-game shooting in India must have noted at times the results of the wild dog pest--whole jungles deserted by game once the animals are aware of the advent of parties of wild dogs.

The Shwe-u-daung sanctuary contains the above mentioned fauna, with the addition of Rhinoceros sumatrensis and the serow. There is reason to believe, says the warden, that the small band of Sumatran rhinoceros living in this sanctuary has become well established, and the evergreen hill forests covering the upper slopes of the sanctuary provide an undisturbed area where these animals can live in peace. The increase in wild dogs is giving trouble here. In the Kahilu sanctuary the animals are Rhinoceros sumatrensis, serow, sambhur, barking deer, mouse deer, hog deer and jungle fowl. It has been proved that the rhinoceros in this sanctuary is $R$. sumatrensis and not $R$. sondaicus, as identified some years ago from skulls by the Bombay Natural History Society. The Sumatran rhinoceros is an extremely rare animal in Burma.

Of the other sanctuaries the Maymyo contains barking deer, jungle fowl, partridge and pea-fowl; Moscos Islands, sambhur, barking deer and pig; Mulayit, barking deer, pig, tiger, and leopard; and the latest made sanctuary, the Wetthigan, which 
includes the lake of that name for the preservation of numerous indigenous and migratory waterfowl, of which thirty-three resident species and thirty-one migratory species have been identified.

It is of interest to hear that the reservation of other sanctuaries is under consideration. The only cause for alarm is the warden's statement that "there is at present no co-ordination between the civil authorities who are responsible for the issue of fire-arms and ammunition, and the Forest Department which is mainly responsible for the protection of wild animals and birds". It is to be hoped that this defect in a far-sighted policy may be removed.

\section{IRISH FISHERIES}

$\mathrm{T}$ HE quantity of sea fish landed in Eire during 1939 was larger than that landed in any year since 1931 , and its value reached the highest figure since 1929 (Department of Agriculture (Fisheries Branch). Report on the Sea and Inland Fisheries for the Year 1959. Dublin, Published by the Stationery Office). The increased landings in 1939 were due to heavier catches of demersal fish by the stream trawlers operating from Dublin, and of mackerel by inshore fishermen on the County of Kerry coast-line. The total catch of whiting in 1939 seems to be the highest recorded for the country, and landings of prime fish, cod and hake, were the heaviest for several years. The quantitative yield of the herring fisheries was less in 1939 than in 1938 , but its total value was greater by $£ 5,000$. The decrease in quantity was due to the failure of the summer fishery of the north-west coast. The substantial increase in the mackerel landings was due to heavier catches in the autumn mackerel fishing off the south-west coast.

The S.S. Muirchu took part during the year in scientific cruises off the north and south-west coasts of Ireland. The cruise off the south-west coast was undertaken in April 1939 for the purpose of continuing the mackerel investigations begun in 1938 in collaboration with the English and French research vessels. As in the previous year mackerel eggs were found in large numbers in an area thirty to seventy miles south to south-south-west of the Fastnet Light. Hydrographic and plankton observations were the main purposes of the cruise off the north coast.

In the inland fisheries the salmon fisheries in 1939 improved but slightly in quantity compared with the years 1937 and 1938, both of which were bad years also for other countries in Western Europe. There was a lack of small and large spring fish such as have spent two or three years respectively in the sea. This was partly compensated for in some parts of the country and particularly in the west by a very good run of grilse.

Artificial propagation of salmon and trout continues, but owing to weather conditions the quantity of ova available was below normal. At the brown trout hatchery at Lough Owel, in spite of weather, there was a record output of 560,000 , some of which were returned to the Lough in the fry stage and others distributed among other stations throughout the country.

Scientific investigations into the age and growth of salmon and other salmon researches are in progress. Seventeen appendixes, mainly statistical, are included in the report.

\section{FORTHCOMING EVENTS}

\author{
Saturday, January 3
}

JoINT MEETING OF TECHNICAI INSTITUTIONS arranged at the request of the Mines Department (in the H. H. Wills Laboratory, Royal
Fort, Bristol), at 2.30 p.m.-Discussion on the Best Ways and Means of Improving the Efficient Use of Fuel and Power in Existing Means of Improving the Efficient Use of Fuel and Power in Existing structive Suggestions. (To be opened by Mr. J. G. Bennett.)

Monday, January 5

Society of Chemicar Industry (Food Group) (at the Chemical Society, Burlington House, Piccadilly, London, W.1), at 2.30 p.m. -Dr. C. A. Freak: "Insecticides".

ROYAL GEOgRaphicaL Society (at Kensington Gore, London, S.W.7), at 3 p.m.-Mr. Patrick FitzGerald: "The Lake Basin of Tali, Yunnan".

Thursday, January 8

Town and Country Planning Association (in the Dome Luunge, Dickins and Jones, 224 Regent Street, London, W.1), at 1.20 p.m.Mr. George Hicks, M.P.: "The Part of the Ministry of Works in Post-War Reconstruction".

\section{Saturday, January 10}

BRITISH INSTITUTION OF RADIO ENGINEERS (at the Federation of British Industries, 21 Tothill Street, London, S.W.1). Dr. W. the Cathode Ray Oscillograph".

\section{APPOINTMENTS VACANT}

Appurcarrons are invited for the following appointments on or before the dates mentioned:

Eddcational Psychologist in connexion with the Child Guidance Clinic-The Director of Education, Education Offices, 15 John Street, Sunderland (January 9).

LrBRARIAN (woMan)-The Principal's Secretary, Royal Holloway College, Englefleld Green, Surrey (January 10).

Electrical Engineer under the Engineer-in-Chief-The Secretary, Tyne Improvement Commission, Newcastle-upon-Tyne 1 (endorsed 'Electrical Engineer') (January 12).

RESEARCH ASSISTANT TO UNDERTAKE WORK ON HOT-TINNING-The Secretary, Tin Research Institute, Fraser Road, Greenford, Middlesex (January 17).

HEAD of THE Physics Department-The Principal and Clerk to the Governing Body, Wigan and District Mining and Technical College, Wigan (January 17).

Educational Psychologist, a Medical Director and PstCHIATRIST, and a PSYCHIATRIC SOCIAL WORKER, in connexion with a Child Guidance Clinic-The Director of Education, Municipal Building, Preston (January 17)

GARDINER CHAIR OF CHEMISTRY - The Acting Secretary, University Court, The University, Glasgow (February 8).

\section{REPORTS and other PUBLICATIONS}

\author{
(not included in the monthly Books Supplement)
}

Great Britain and Ireland

Tin Research Institute. Publication No. 106: The Longitudinal Ridged Structure in the Tin Coating of Tinplate. By Dr. B. Chalmers and W. E. Hoare. Pp. $8+1$ plate. (Greenford: Tin Research Institute.)

\section{Other Countries}

Smithsonian Miscellaneous Collections. Vol. 99, No. 22: The Ice Age Problem. By Walter Knoche. (Publication 3633.) Pp. ii +5 . (Washington, D.C.: Smithsonian Institution.) [2511

Transactions of the San Diego- Society. of Natural History. Vol. 9, No. 27: The Distribution of Pocket Gophers in Southeastern California. By John E. Chattin. Pp. 265-284. (San Diego, Calif.: San Diego Society of Natural History.)

University of California Publications in Zoology. Vol. 44, No. 2 . University of California Publications in Zoology. Vol. 44, No. 2: A Field Study of the Growth and Behaviour of the Fence Lizard. By Henry S. Fitch. Pp. 151-172. 25 cents. Vol. 44, No. 3 : Speciation in the A vian Genus Junco. By Alden H. Miller. Pp. 173-434. 3 dollars. (Berkeley, Calif.: University of California Press ; London :
Cambridge University Press.) Smithsonian Miscellaneous Collections. Vol. 99, No. 23 : Evidences
of Early Occupation in Sandia Cave, New Mexico, and other Sites in the Sandia-Manzano Region. By Frank C. Hibben. With Appendix on Correlation of the Deposits of Sandia Cave, New Mexico, with the Glacial Chronology, by Kirk Bryan. (Publication 3636.) Pp. vi $+64+$ 15 plates. (Washington, D.C.: Smithsonian Institution.) Records of the Botanical Survey of India. Vol. 14, No. 2: A Revision of the Indo-Malayan Species of Glycosmis correa. By V. Narayanaswami. Pp. v+72+ii. (Delhi : Manager of Publications.) Narayanaswami. Pp. $\mathrm{v}+72+\mathrm{ii}$. (Delhi: Manager of Publications.)
4.6 rupees ; 78. Indian Forest Records (New Series.) Botany, Vol. 2, No. 2: Thyr8ostachys oliveri Gamble. By Dr. N. L. Bor. Pp. $217-226+2$ plates. 10 annas; 18. Entomology, Vol. 6, No. 9: Immature Stages of Indian Lepidoptera (3). By J. C. M. Gardner. Pp. 297-314 +1 plate.

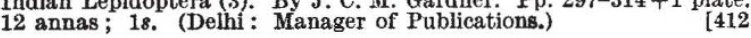

